MaPan : Jurnal Matematika dan Pembelajaran

p-ISSN: 2354-6883 ; e-ISSN: 2581-172X

Volume 4, Nomor 2, Desember 2016

\title{
HUBUNGAN KECERDASAN EMOSIONAL TERHADAP PRESTASI BELAJAR MAHASISWA DITINJAU DARI JENIS KELAMIN PADA JURUSAN PENDIDIKAN MATEMATIKA UIN ALAUDDIN MAKASSAR
}

\author{
Irmawati1), Thamrin Tayeb2), Ridwan Idris ${ }^{3)}$ \\ 1,2,3Fakultas Tarbiyah dan Keguruan UIN Alauddin Makassar \\ 1,2,3Kampus II: Jalan H. M. Yasin Limpo Nomor 36 Samata-Gowa \\ E-mail: syahidah_irmawati@yahoo.co.uk1) , thamrinthayeb@yahoo.com ${ }^{2}$,
} ridwanidris34@gmail.com ${ }^{3}$

\begin{abstract}
Abstrak
Penelitian ini bertujuan untuk mengetahui bagaimana gambaran kecerdasan emosional mahasiswa, prestasi belajar matematika serta hubungan antara kecerdasan emosional dengan prestasi belajar mahasiswa ditinjau dari jenis kelamin pada Jurusan Pendidikan Matematika Universitas Islam Negeri Alauddin Makassar. Jenis penelitian yang digunakan dalam penelitian ini adalah penelitian ex post facto. Penelitian ini dilakukan di kampus I dan kampus II UIN Alauddin Makassar angkatan 2012, 2013 dan 2014 sebanyak 326 dengan sampel sebanyak 30\% dari populasi yaitu 98 orang yang terdiri dari 49 laki-laki dan 49 perempuan, dengan teknik simple random sampling. Hasil penelitian yang diperoleh adalah kecerdasan emosional mahasiswa laki-laki dan perempuan jurusan pendidikan berada dalam kategori sedang dengan masing-masing skor rata-rata 76,04 dan 73,98, dan prestasi belajar mahasiswa laki-laki dan perempuan jurusan pendidikan matematika berada dalam kategori memuaskan dengan masing-masing skor rata-rata 3,46 dan 3,49. Penelitian ini menyimpulkan bahwa tidak ada hubungan kecerdasan emosional terhadap prestasi belajar mahasiswa ditinjau dari jenis kelamin pada jurusan pendidikan matematika angkatan 2012, 2013, dan 2014 UIN Alauddin Makassar dengan taraf signifikan 5\% atau $(\alpha=0,05)$.
\end{abstract}

Kata Kunci: Kecerdasan Emosional, Prestasi Belajar, Jenis Kelamin

$\mathrm{P}$ eran pendidikan dalam suatu bangsa itu sangatlah penting. Kualitas atau mutu pendidikan di dalam suatu bangsa sangatlah menentukan maju tidaknya bangsa tersebut. Oleh karena itu, pembaharuan pendidikan harus terus dilakukan untuk meningkatkan kualitas atau mutu pendidikan suatu bangsa, sehingga bangsa tersebut bisa maju. Pendidikan adalah usaha sadar dan terencana untuk mewujudkan suasana belajar dan proses pembelajaran agar peserta didik secara aktif mengembangkan potensi dirinya untuk memiliki kekuatan spiritual keagamaan, pengendalian diri, 
kepribadian, kecerdasan, akhlak mulia, serta keterampilan yang diperlukan dirinya, masyarakat, bangsa dan negara.

Kesuksesan dalam dunia pendidikan tidak hanya bergantung pada kecerdasan intelektual (IQ) saja tetapi juga sangat ditentukan oleh seberapa besar tingkat kecerdasan emosional (EQ) dari peserta didik. Hal inilah yang harus menjadi sorotan sebagai pengajar untuk membekali peserta didik tidak hanya pada kecerdasan intelektual akan tetapi juga kecerdasan emosional. Ketika hasil pengukuran IQ anak di Sekolah menunjukkan skor di atas 120 misalnya, sejumlah orang tua beranggapan bahwa anaknya demikian pandai dan kelak tidak akan menghadapi banyak masalah dalam hidupnya.

Namun ketika seseorang belajar dengan baik menggunakan dan mengembangkan kecerdasan emosional, berarti telah mendapatkan pengaturan yang paling penting dari keterampilan dan kompetensi untuk keberhasilan dan kesehatan sepanjang hidup. John menyatakan:

"Emotional intelligence is about knowing what you are feeling, and beingable to motivate yourself to get jobs done. It is sensing what others are feeling and handling relationships effectively."

Pendapat ini mengungkapkan bahwa kecerdasan emosional adalah mengenai bagaimana seseorang mengetahui apa yang dirasakan yang mampu memotivasi diri sendiri untuk bisa melakukan tugas-tugas dengan lebih baik sehingga akan mampu menjalin hubungan yang lebih baik dengan pihak lain

Pembelajaran matematika tidak hanya memiliki tujuan material saja yaitu peserta didik mampu menerapkan dan terampil dalam matematika dan menjadikan prestasi belajar mereka bagus. Tetapi pembelajaran matematika juga memiliki tujuan membentuk kepribadian peserta didik. Kepribadian maksudnya disini adalah kepribadian sikap (emosi). dari kemampuan menerapkan dan terampil dalam matematika itulah akan diketahui prestasi belajar matematika yang diperoleh peserta didik. Hal ini berdasarkan penelitian yang dilakukan oleh James D.A. Parker dengan judul" Academic achievement in high school: does emotional intelligence matter" menyatakan bahwa keberhasilan akademis sangat terkait dengan beberapa dimensi kecerdasan emosional. Senada dengan penelitian yang dilakukan oleh Carolyn Mac Caan dengan Judul"Coping Medied the Relationship between intelligence (EI) and academic achievement" menyatakan bahwa hasil pendidikan yang lebih baik mungkin dicapai dengan menargetkan keterampilan dengan manajemen emosi dan mengatasi masalah. Adapun penelitian yang dilakukan oleh Bhadouria Preeti dengan Judul "Role of Emotional Intelligence for academic 
achievement forStudents" dalam penelitiannya Bhadoria Preeti menyatakan bahwa prestasi akademik tanpa kecerdasan emosional tidak menunjukkan kesuksesan masa depan dan tidak adanya kecerdasan emosional juga menunjukkan kepribadian dan kemampuan untuk membangun hubungan ditempat bekerja juga di sekolah dan itu sangat penting bagi kualitas pendidikan.

Salah satu indikator lain, keberhasilan suatu pendidikan dapat dilihat dari prestasi belajar siswa. Prestasi belajar merupakan pengukuran dan penilaian hasil belajar yang telah dilakukan oleh mahasiswa setelah mahasiswa melakukan kegiatan proses pembelajaran yang kemudian dibuktikan dengan suatu tes dan hasil pembelajaran tersebut dinyatakan dalam bentuk simbol baik dalam bentuk angka, huruf maupun kalimat yang menceritakan hasil yang sudah dicapai. Dalam pendidikan formal, dengan prestasi belajar dapat diketahui kedudukan mahasiswa yang pandai, sedang, atau lambat.

Terdapat banyak faktor yang mempengaruhi prestasi atau keberhasilan seorang mahasiswa dalam belajar di perguruan tinggi. Faktor-faktor tersebut antara lain kecerdasan intelektual, kondisi sosial ekonomi mahasiswa yang bersangkutan, minat dan kemauan belajar mahasiswa dan sebagainya. Namun ada satu faktor penting lainnya yang layak dan harus kita perhatikan dalam kaitannya dengan prestasi belajar mahasiswa yaitu kecerdasan emosional mahasiswa yang bersangkutan. Hal ini disebabkan karena kecerdasan emosional ternyata lebih banyak memberikan motivasi kepada personal untuk mencari manfaat dan potensi unik mereka, serta mengaktifkan aspirasi dan nilai-nilai yang paling dalam, mengubahnya dari apa yang mereka pikirkan menjadi apa yang mereka jalani dalam aktivitas sehari-hari. Jenis kelamin merupakan salah satu faktor yang dapat mempengaruhi kecerdasan emosional. Oleh karena itu, penelitian ini bermaksud mengetahui hubungan antara kecerdasan emosional dengan prestasi belajar mahasiswa ditinjau dari jenis kelamin pada Jurusan Pendidikan Matematika Universitas Islam Negeri Alauddin Makassar.

\section{PRESTASI BELAJAR MATEMATIKA}

Belajar adalah mengumpulkan sejumlah pengetahuan. Pengetahuan tersebut diperoleh dari seseorang yang lebih tahu, seperti dari guru. Orang yang banyak pengetahuannya dipandang seebagai orang yang banyak belajar. Sebaliknya orang yang seddikit pengetahuannya dipandang seebagai orang 
yang sedikit belajar. Sedangkan orang yang tidak berpengetahuan dipandang sebagai orang yang tidak belajar. Secara psikologis, belajar merupakan suatu proses perubahan yaitu perubahan tingkah laku sebagai hasil dari interaksi dengan lingkungannya dalam memenuhi kebutuhan hidupnya. Perubahanperubahan tersebut akan nyata dalam seluruh aspek tingkah laku. Pengertian belajar dapat didefenisikan sebagai suatu proses usaha yang dilakukan seseorang untuk memperoleh suatu perubahan tingkah laku yang baru secara keseluruhan, sebagai hasil pengalamannya sendiri dalam interaksi dengan lingkungannya. Jadi proses belajar itu mengakibatkan perubahan pola tingkah laku yang disebabkan oleh pengalaman-pengalaman.

\section{KECERDASAN EMOSIONAL}

Istilah kecerdasan emosional atau "Emotional Intellingence" pertama kali dilontarkan pada tahun 1990 oleh psikolog Peter Salovey dari Harvard University dan John Mayer dari University of New Hampshire. Menurut Binet, kecerdasan adalah kecendrungan untuk mengambil dan mempertahankan pilihan yang tetap, kapasitas untuk beradaptasi dengan maksud memperoleh tujuan yang diinginkan dan kekuatan untuk autokritik. Sedangkan menurut D. Wechsler kecerdasan adalah kumpulan kapasitas atau kapasitas global individu untuk berbuat menurut tujuannya secara tepat, berpikir secara rasional, dan menghadapi alam sekitar secara efektif.

Gardner dalam bukunya yang berjudul Frame of Mind menyatakan bahwa bukan hanya satu jenis kecerdasan yang monolitik yang penting untuk meraih sukses dalam kehidupan, melainkan ada spektrum kecerdasan yang lebar dengan tujuh varietas utama yaitu linguistik, matematika/logika, spasial, kinestetik, musik, intepersonal, dan intrapersonal. Kecerdasan ini dinamakan oleh Gardner sebagai kecerdasan pribadi yang oleh Daniel Goleman disebut sebagai kecerdasan emosional. Goleman mengutip Salovey menempatkan kecerdasan pribadi Gardner dalam defenisi dasar tentang kecerdasan emosional yang dicetuskannya, seraya memperluas kemampuan ini menjadi lima wilayah utama, yaitu:

a. Mengenali Emosi Diri.

Mengenali emosi diri merupakan dasar kecerdasan emosional kesadaran akan perasaan diri sendiri sewaktu perasaan itu timbul. Kemampuan ini merupakan dasar dari kecerdasan emosional, para ahli psikologi menyebutkan kesadaran diri sebagai metamood yakni kesadaran seseorang akan emosinya sendiri. Menurut John Mayer kesadaran diri adalah 
adalah waspada terhadap suasana hati maupun pikiran tentang suasana hati, bila kurang waspada maka individu akan menjadi mudah larut dalam aliran emosi dan dikuasai oleh emosi. Kesadaran diri memang belum menjamin penguasaan emosi, namun merupakan salah satu prasyarat penting untuk mengendalikan emosi sehingga individu mudah menguasai emosi.

b. Mengelola Emosi

Mengelola emosi merupakan kemampuan individu dalam menangani perasaan agar dapat terungkap dengan tepat atau selaras, sehingga tercapai keseimbangan dalam diri individu. Menjaga agar emosi yang merisaukan tetap terkendali merupakan kunci menuju kesejahteraan emosi. Emosi berlebihan, yang meningkat dengan intensitas terlampau lama akan mengoyak kestabilan kita. Kemampuan ini mencakup kemampuan untuk menghibur diri sendiri, melepaskan kecemasan, kemurungan atau ketersinggungan dan akibat-akibat yang ditimbulkannya serta kemampuan untuk bangkit dari perasaan-perasaan yang menekan.

c. Memotivasi Diri Sendiri

Memotivasi diri sendiri adalah hal yang sangat penting dalam kaitan untuk memberi perhatian, untuk memotivasi diri sendiri, menguasai diri sendiri, dan untuk berkreasi. Dalam hal ini prestasi harus dilalui dengan dimilikinya motivasi dalam diri individu, yang berartimemiliki ketekunan untuk menahan diriterhadap kepuasan dan mengendalikan dorongan hati, serta mempunyai perasaan motivasi yang positif, yaitu antusianisme, gairah, optimis, dan keyakinan diri.

d. Mengenali Emosi Orang Lain

Kemampuan untuk mengenali emosi orang lain disebut juga empati. Menurut Goleman kemampuan seseorang untuk mengenali orang lain atau peduli, menunjukkan kemampuan empati seseorang. Individu yang memiliki kemampuan empati lebih mampu menangkap sinyal-sinyal sosial yang tersembunyi yang mengisyaratkan apa-apa yang dibutuhkan orang lain sehingga ia mampu menurut sudut pandang orang lain, peka terhadap perasaan orang lain dan lebih mampu untuk mendengarkan orang lain.

e. Membina Hubungan

Kemampuan dalam membina hubungan merupakan suatu keterampilan yang panjang popularitas, kepemimpinan dan keberhasilan antar pribadi. Keterampilan dalam berkomunikasi merupakan kemampuan dasar dalam keberhasilan membina hubungan. Kemampuan sosial ini memungkinkan seseorang membentuk hubungan, untuk menggerakkan dan 
mengilhami orang-orang lain, membina kedekatan hubungan, menyakinkan dan mempengaruhi, membuat orang lebih merasa nyaman.

\section{METODE PENELITIAN}

Jenis dari penelitian ini adalah penelitian ex post facto. Penelitian ini dilaksanakan di kampus I Universitas Islam Negeri (UIN) Alauddin Makassar yang berlokasi di Jl. Sultan Alauddin No.63 untuk angkatan 2013, dan Kampus II Fakultas Tarbiyah dan Keguruan Universitas Islam Negeri (UIN) Alauddin Makassar yang berlokasi di Jl.H.M.Yasin Limpo No. 36 Samata Sungguminasa untuk angkatan 2012, 2013 dan 2014 dengan subyek penelitian mahasiswa Jurusan Pendidikan Matematika. Populasi yang peneliti ambil dalam penelitian ini adalah mahasiswa Jurusan Pendidikan Matematika yang terdiri dari angkatan 2012 yang berjumlah 140 orang, 2013 yang berjumlah 113 orang, dan angkatan 2014 yang berjumlah 73 orang dengan jumlah keseluruhan 326 orang. Jumlah sampel yang digunakan peneliti yaitu 30\% dari jumlah populasi yaitu 97,8 (dibulatkan 98) orang.

Instrumen yang digunakan untuk mengukur kecerdasan emosianal adalah angket tertutup (close form). Ada dua macam statistik yang digunakan untuk analisis data dalam penelitian, yaitu statistik deskriptif dan statistik inferensial. Uji prasyarat dalam penelitian ini adalah uji normalitas, uji linearitas, uji korelasi selanjutnya pengujian hipotesis.

\section{HASIL PENELITIAN DAN PEMBAHASAN}

Gambaran Kecerdasan Emosional mahasiswa ditinjau dari jenis kelamin pada Jurusan Pendidikan Matematika Universitas Islam Negeri Alauddin Makassar.

Tabel 1. Persentase Kecerdasan Emosional Mahasiswa Laki-Laki Jurusan Pendidikan Matematika

\begin{tabular}{ccccc}
\hline Batas Kategori & Interval & Frekuensi & $\begin{array}{c}\text { Persentase } \\
\mathbf{( \% )}\end{array}$ & Ket. \\
\hline$x<(\mu-1,0 \sigma)$ & $x<50$ & 0 & 0 & Rendah \\
$(\mu-1,0 \sigma) \leq x \leq(\mu+1,0 \sigma)$ & $50 \leq x \leq 75$ & 29 & 59,2 & Sedang \\
$x>(\mu+1,0 \sigma)$ & $x>75$ & 20 & 40,8 & Tinggi \\
\hline Total & & 49 & 100 & \\
\hline
\end{tabular}


Berdasarkan tabel di atas dinyatakan bahwa tidak terdapat mahasiswa laki-laki atau 0\% memiliki kecerdasan emosional yang rendah, 29 atau 59,2\% memiliki tingkat kecerdasan emosional yang sedang, dan 20 atau 40,8\% kecerdasan emosional yang tinggi. Dengan demikian dapat disimpulkan bahwa sebagian besar kecerdasan emosional mahasiswa laki-laki jurusan pendidikan matematika tergolong sedang.

Tabel 2. Persentase Kecerdasan Emosional Mahasiswa Perempuan Jurusan Pendidikan Matematika

\begin{tabular}{ccccc}
\hline Batas Kategori & Interval & Frekuensi & $\begin{array}{c}\text { Persentase } \\
\mathbf{( \% )}\end{array}$ & Ket. \\
\hline$x<(\mu-1,0 \sigma)$ & $x<50$ & 0 & 0 & Rendah \\
$(\mu-1,0 \sigma) \leq x \leq(\mu+1,0 \sigma)$ & $50 \leq x \leq 75$ & 25 & 51 & Sedang \\
$x>(\mu+1,0 \sigma)$ & $x>75$ & 24 & 49 & Tinggi \\
\hline Total & & 49 & 100 & \\
\hline
\end{tabular}

Berdasarkan tabel di atas dinyatakan bahwa tidak terdapat mahasiswa perempuan atau $0 \%$ memiliki kecerdasan emosional yang rendah, 25 atau 51\% memiliki tingkat kecerdasan emosional yang sedang, 24 atau 49\% kecerdasan emosional yang tinggi. Dengan demikian dapat disimpulkan bahwa sebagian besar kecerdasan emosional mahasiswa perempuan jurusan pendidikan matematika tergolong sedang.

Hasil dari pengolahan data angket sebanyak 98 mahasiswa yang terdiri 49 mahasiswa laki-laki dan 49 mahasiswa perempuan, berasal dari angkatan 2012, 2013, dan 2014. Pada pengolahan data 49 mahasiswa laki-laki diperoleh skor kecerdasan emosional tertinggi sebesar 92 dan terendah sebesar 58 sehingga rentang kelasnya (range) yaitu sebesar 34, kelas interval sebesar 7 serta panjang kelas sebesar 5. Rata-rata skor (Maen) yang diperoleh sebesar 73,98 dengan standar deviasi sebesar 6,80 yang berarti bahwa data yang diperoleh heterogen dan memiliki kecendrungan yang berbeda antara satu dengan yang lainnya. Hasil kategorisasi kecerdasan emosinal yang diperoleh menunjukkan bahwa 20 orang mahasiswa laki-laki dengan persentase 40,8\% berada dalam kategori tinggi, 29 orang mahasiswa laki-laki dengan persentase $59,2 \%$ berada pada kategori sedang, dan tidak ada mahasiswa laki-laki berada pada kategori rendah. 
Hasil dari pengolahan data 49 mahasiswa perempuan diperoleh skor kecerdasan emosional sebesar tertinggi sebesar 90 dan terendah sebesar 57 sehingga rentang kelasnya (range) yaitu sebesar 33, kelas interval sebesar 7 serta panjang kelas sebesar 5. Rata-rata skor (Maen) yang diperoleh sebesar 76,04 dengan standar deviasi sebesar 6,11 yang berarti bahwa data yang diperoleh heterogen dan memiliki kecendrungan yang berbeda antara satu dengan yang lainnya. Hasil kategorisasi kecerdasan emosinal yang diperoleh menunjukkan bahwa 24 orang mahasiswa perempuan dengan persentase 49,0\% berada dalam kategori tinggi, 25 orang mahasiswa perempuan dengan persentase $51,0 \%$ berada pada kategori sedang, dan tidak ada mahasiswa perempuan berada pada kategori rendah. Berdasarkan hasiil dari pengolahan data angket menunjukkan bahwa skor kecerdasan emosional pada mahasiswa laki-laki dan mahasiswa perempuan tidak jauh berbeda.

Hal ini mengidentifikasikan bahwa mahasiswa pendidikan matematika angkatan 2012, 2013, dan 2014 Fakultas Tarbiyah dan Keguruan UIN Alauddin Makassar memiliki rata-rata kecerdasan emosional berada pada kategori sedang. Artinya pada umumnya mahasiswa laki-laki dan mahasiswa perempuan telah memiliki kemampuan mengungkapkan perasaan positif, afirmasi diri dan mengungkapkan perasaan negatif yang merupakan aspek utama yang cukup baik meskipun belum maksimal.

\section{Gambaran Prestasi Belajar mahasiswa ditinjau dari jenis kelamin pada jurusan Pendidikan Matematika Universitas Islam Negeri Alauddin Makassar}

Tabel 3: Kategorisasi Prestasi Belajar Mahasiswa Laki-Laki Jurusan Pendidikan Matematika

\begin{tabular}{rcccc}
\hline No. & Indeks Prestasi & Predikat & Frekuensi & $\begin{array}{c}\text { Persentase } \\
\mathbf{( \% )}\end{array}$ \\
\hline 1. & $3,76-4,00$ & Cumlaude & 5 & 10,21 \\
2. & $3,51-3,75$ & Sangat memuaskan & 18 & 36,73 \\
3 & $2,00-3,50$ & Memuaskan & 26 & 53,06 \\
\hline & & 49 & 100 \\
\hline
\end{tabular}

Berdasarkan tabel di atas dinyatakan bahwa terdapat 26 mahasiswa laki-laki atau 53,06\% memiliki prestasi belajar yang memuaskan, 18 atau $36,73 \%$ memiliki prestasi belajar yang sangat memuaskan, dan 5 atau 10,21\% 
memiliki prestasi belajar yang cumlade. Dengan demikian dapat disimpulkan bahwa sebagian besar prestasi belajar mahasiswa laki-laki jurusan pendidikan matematika tergolong memuaskan.

Tabel 1: Kategorisasi Prestasi Belajar Mahasiswa Perempuan Jurusan Pendidikan Matematika

\begin{tabular}{ccccc}
\hline No. & Indeks Prestasi & Predikat & Frekuensi & Persentase (\%) \\
\hline 1. & $3,76-4,00$ & Cumlaude & 3 & 6,12 \\
2. & $3,51-3,75$ & Sangat memuaskan & 21 & 42,86 \\
3 & $2,00-3,50$ & Memuaskan & 25 & 51,02 \\
\hline \multicolumn{2}{r}{ Jumlah } & 49 & 100 \\
\hline
\end{tabular}

Berdasarkan tabel di atas dinyatakan bahwa terdapat 25 atau 51,02\% mahasiswa perempuan memiliki prestasi belajar yang memuaskan, 21 atau $42,86 \%$ memiliki prestasi belajar yang sangat memuaskan, 3 atau 6,12\% memiliki prestasi belajar cumlade. Dengan demikian dapat disimpulkan bahwa sebagian besar prestasi belajar mahasiswa perempuan jurusan pendidikan matematika tergolong memuaskan.

Hasil dari analisis statistik deskriptif prestasi belajar mahasiswa lakilaki diperoleh nilai tertinggi sebesar 3,94 sedangkan nilai terendah sebesar 3,04 sehingga rentang kelasnya (range) sebesar 0,90, kelas interval sebesar 7 serta panjang kelas 0,13. Rata-rata skor (Mean) yang diperoleh sebesar 3,46 dengan standar deviasi sebesar 0,22, sehingga data yang diperoleh homogen dan memiliki kecerndrungan yang sama antara satu dengan yang lainnya. Hasil kategorisasi prestasi belajar yang diperoleh menunjukkan bahwa 26 orang mahasiswa dengan persentase 53,06\% berada dalam kategori memuaskan, 18 orang mahasiswa dengan persentase $36,73 \%$ pada kategori sangat memuaskan, dan 5 orang mahasiswa dengan persentase $10,21 \%$ pada kategori cumlade. Sedangkan hasil analisis statistik deskriptif pada 49 mahasiswa perempuan diperoleh nilai tertinggi sebesar 3,85 sedangkan nilai terendah sebesar 2,98 rata skor (Mean) yang diperoleh sebesar 3,49 dengan standar deviasi sebesar 0,18 , sehingga data yang diperoleh homogen dan memiliki kecerndrungan yang sama antara satu dengan yang lainnya. Hasil kategorisasi prestasi belajar yang diperoleh menunjukkan bahwa 25 orang mahasiswa dengan persentase $51,02 \%$ berada dalam kategori memuaskan, 21orang mahasiswa dengan persentase $48,82 \%$ pada kategori sangat memuaskan, dan 3 
orang mahasiswa dengan persentase 6,12\% pada kategori cumlade. Berdasarkan hasiil dari analisis statistik deskriptif prestasi belajar mahasiswa jurusan pendidikan matematika tidak jauh berbeda.

Berdasarkan dokumentasi prestasi belajar mahasiswa pendidikan matematika angkatan 2012, 2013 dan 2014, diperoleh kategori rata-rata prestasi belajar yaitu memuaskan yang didasarkan pada kategori yang telah berlaku pada UIN Alauddin makassar yaitu:

$$
\begin{array}{ll}
3,76-4,00 & =\text { Cumlaude } \\
3,51-3,75 & =\text { Sangat Memuaskan } \\
2,00-3,50 & =\text { Memuaskan }
\end{array}
$$

Indeks Prestasi yang diperoleh merupakan akumulasi dari semua nilai mata kuliah yang telah diikuti yang diperoleh dari dokumentasi dari Jurusan Pendidikan Matematika di semester III, V, dan VII.

\section{Hubungan Kecerdasan Emosional terhadap Prestasi Belajar Mahasiswa Ditinjau Dari Jenis Kelamin Pada Jurusan Pendidikan Matematika UIN Alauddin Makassar}

Untuk menjawab rumusan masalah ketiga sekaligus menjawab hipotesis dalam penelitian ini dilakukan dengan menggunakan statistika inferensial yaitu dengan menggunakan analisis korelasi sederhana. Agar dapat menggunakan analisis korelasi, data hasil penelitian harus berdisitribusi normal dan memiliki hubungan linier antara kedua variabel. Maka dilakukanlah uji prasyarat yaitu uji normalitas, yang mana dilakukan dengan bantuan program komputer Statistical Packages for Social Sciences (SPSS) versi 20.0 .

\section{a. Uji Normalitas}

Uji normalitas dilakukan untuk mengetahui normal tidaknya sebaran skor variabel kecerdasan emosional dan prestasi belajar matematika ditinjau dari kecerdasan emosional pada jurusan pendidikan matematika. Pengujian normalitas ini dilakukan dengan menggunakan SPSS versi 20. Jika data tersebut berdistribusi normal maka Sig $>a=0,05$ dan jika data tersebut tidak berdistribusi normal maka Sig $<\alpha=0,05$.

Berdasarkan hasil pengolahan data dengan SPSS Versi 20 di atas maka didapatlah nilai sign atau $p$-Value untuk data kecerdasan emosional mahasiswa laki-laki adalah sebesar 0,639 . Berarti nilai sign atau $p$-Value lebih besar dari nilaia $(0,639>0,05)$ dan pada prestasi belajar mahasiswa laki-laki 
didapatkan nilai Sig lebih besar dari nilai a $(0,815>0,050)$ pada taraf signifikan $a=0,05$, maka data dikatakan berdistribusi normal.

Berdasarkan hasil pengolahan data dengan SPSS Versi 20, maka didapatlah nilai sign atau $p$-Value untuk data kecerdasan emosional mahasiswa perempuan adalah sebesar 0,849. Berarti nilai sign atau $p$-Value lebih besar dari nilaia $(0,849>0,05)$ dan pada prestasi belajar mahasiswa perempuan didapatkan nilai Sig lebih besar dari nilai a $(0,779>0,050)$ pada taraf signifikan $\alpha=0,05$, maka data dikatakan berdistribusi normal.

\section{b. Uji Linearitas (Kelinearan Persamaan Regresi)}

Uji linearitas adalah uji yang akan memastikan apakah data yang kita miliki sesuai dengan garis linear atau tidak. Uji linearitas digunakan untuk mengkonfirmasikan apakah sifat linear antara dua variabel yang diidentifikasikan secara teori sesuai atau tidak dengan hasil observasi yang ada. Taraf signifikan 0,05 dan derajat kebebasan pembilang n-1 serta derajat kebebasan penyebut n-1, maka jika diperoleh Fhitung >Ftabel berarti data linear.

Untuk membuktikan bahwa ada atau tidak hubungan antara kecerdasan emosional dengan Prestasi Belajar Mahasiswa Jurusan Pendidikan matematika digunakan rumus Korelasi Pearson Product Moment. Hasil uji korelasi antara variabel $\mathrm{X}$ dan $\mathrm{Y}$ dengan menggunakan Statistical Product And Service Solution (SPSS) versi 20,0 yaitu uji linieritas Perilaku Asertif terhadap Prestasi Belajar diperoleh nilai sig. 0,952 >a(0,05) yang berarti data tersebut linear.

\section{c. Uji Korelasi}

Untuk membuktikan bahwa ada atau tidak hubungan antara kecerdasan emosional dengan Prestasi Belajar Mahasiswa laki-laki dan perempuan pada Jurusan Pendidikan Matematika digunakan rumus Korelasi Pearson Product Moment dengan menggunakan Statistical Product And Service Solution (SPSS) versi 20,0.

Setelah dilakukan analisis statistik inferensial menggunakan korelasi product moment koefisien korelasi pada mahasiswa laki-laki dan perempuan diperoleh masing-masing sebesar rhitung $=0,184$ dan 0,116 tidak terdapat korelasi yang signifikan, melalui uji signifikansi diperoleh masing-masing thitung 0,207 dan thitung 0,427 atau $\mathrm{p}>0,05$. Dengan demikian, H0 diterima dan H1 ditolak. Hal ini berarti hipotesis asli tentang tidak ada hubungan 
kecerdasan emosional terhadap prestasi belajar mahasiswa laki-laki dan perempuan pada jurusan pendidikan matematika angakatan 2012, 2013, dan 2014.

Setelah dilakukan analisis statistik inferensial menggunakan korelasi product moment koefisien korelasi yang diperoleh sebesar $\mathrm{r}_{\text {hitung0,164 }} \leq r_{\text {tabel }}=$ 0,167 terdapat korelasi yang signifikan melalui uji signifikansi diperoleh masing-masing 0,207 dan thitung 0,427 atau $\mathrm{p}>0,05$. Dengan demikian, $\mathrm{H}_{0}$ diterima dan $\mathrm{H}_{1}$ ditolak. Hal ini berarti hipotesis asli tentang tidak ada hubungan kecerdasan emosional terhadap prestasi belajar mahasiswa laki-laki dan perempuan pada jurusan pendidikan matematika angakatan 2012, 2013, dan 2014. Sehingga keputusan penelitian ini adalah menerima hipotesis penelitian yang diajukan yakni terdapat hubungan hubungan kecerdasan emosional terhadap prestasi belajar mahasiswa ditinjau dari kecerdasan emosional pada jurusan pendidikan matematika angkatan 2012, 2013 dan Angkatan 2014 Fakultas Tarbiyah dan Keguruan Universitas Islam Negeri Alauddin Makassar.

Kecerdasan emosional perlu diasah sejak dini karena kecerdasan emosional merupakan salah satu proses keberhasilan individu dalam berbagai aspek kehidupan. Kemampuan anak mengembangkan kecerdasan emosinya, berkorelasi positif dengan keberhasilan akademis, sosial dan kesehatan mentalnya. Anak yang memiliki kecerdasan emosional tinggi identik dengan anak yang bahagia, bermotivasi tinggi, dan mampu bertahan dalam menjalani berbagai kondisi stres yang dihadapi.

Berbagai penelitian dalam bidang psikologi anak telah membuktikan bahwa anak-anak yang memiliki kecerdasan emosional yang tinggi adalah anak-anak yang bahagia, popular, percaya diri, dan lebih sukses di Sekolah/Perguruan Tinggi. Mereka lebih mampu menguasai gejolak emosi, menjalin hubungan yang manis dengan orang lain, dapat mengelola stres, dan memiliki kesehatan mental yang baik.

Menurut Daniel Goleman, IQ hanya mendukung sekitar 20\% yang menentukan suatu keberhasilan, $80 \%$ sisanya berasal dari faktor lain, termasuk kecerdasan emosional. Penelitian terobosan ini memiliki berbagai implikasinya bagi lingkungan bisnis dan bagaimana cara mengelola diri sendiri dengan orang lain.kecerdasan emosional mencakup semua sikap atau kemampuan pribadi seperti mengelola emosi sendiri, memotivasi diri, mengenal emosi orang lain, dan membina hubungan sosial. 


\section{KESIMPULAN}

Berdasarkan hasil penelitian dan analisis data pada bab sebelumnya maka dapat ditarik kesimpulan sebagai berikut:

a. Kecerdasan emosional mahasiswa laki-laki dan perempuan memiliki ratarata masing-masing 76,04 dan 73,98 dengan standar deviasi masing-masing 6,11 dan 6,80. Hal ini menunjukkan bahwa rata-rata kecerdasan emosional laki-laki lebih tinggi dibanding dengan perempuan. Sedangkan kategori masing-masing mahasiswa laki-laki dan perempuan berada pada kategori sedang yaitu 25 orang mahasiswa laki-laki dengan persentase 51,0\% dan 29 orang mahasiswa perempuan dengan persentase $59,2 \%$.

b. Prestasi belajar mahasiswa laki-laki dan perempuan memiliki rata-rata masing-masing 3,46 dan 3,49 dengan standar deviasi masing-masing sebesar 0,22 dan 0,18. Hal ini menunjukkan bahwa prestasi belajar mahasiswa laki-laki dan perempuan tidak jau berbeda. Sedangkan kategori prestasi belajar dari masing-masing mahasiswa laki-laki dan mahasiswa perempuan berada pada kategori memuaskan yaitu 26 orang mahasiswa laki-laki dengan persentase 53,06\% dan 25 orang mahasiswa perempuan dengan persentase $51,02 \%$.

c. Hubungan antara kecerdasan emosional dengan prestasi belajar Mahasiswa ditinjau dari jenis kelamin pada Jurusan Pendidikan Matemtika Fakultas Tarbiyah Dan Keguruan Universitas Islam Negeri Alauddin Makassar, memiliki hubungan yang berada pada kategori sangat rendah. Hasil analisis korelasi Product Moment pada mahasiswa laki-laki dan perempuan diperoleh masing-masing sebesar $r_{\text {hitung }}$ 0,184 dan 0,116 terdapat korelasi yang signifikan meskipun korelasinya berada pada kategori sangat rendah, Hasil analisis menggunakan korelasi Product Moment pada mahasiswa laki-laki dan perempuan diperoleh masingmasing sebesar $r_{\text {hitung }}$ 0,184 dan 0,116 dengan angka signifikansi yang diperoleh masing-masing sebesar 0,207 dan 0,427 atau $\mathrm{p}>0,05$ maka $\mathrm{H}_{1}$ ditolak dan $\mathrm{H}_{0}$ diterima. Kesimpulan dari penelitian ini yaitu tidak ada hubungan kecerdasan emosional terhadap prestasi belajar mahasiswa ditinjau dari jenis kelamin pada jurusan pendidikan matematika angkatan 2012, 2013, dan 2014 UIN Alauddin Makassar dengan taraf signifikan 5\% atau $(\alpha=0,05)$. 


\section{DAFTAR PUSTAKA}

Abdurrahman, M. (1999). Pendidikan bagi anak kesulitan belajar. Cet I; Jakarta: PT Rineka Cipta.

Arikunto, S. (2006). Prosedur penelitian suatu pendekatan praktik. Jakarta: Rineka Cipta.

Azwar, S. (2013). Penyusunan skala psikologi. Yogyakarta: Pustaka Pelajar.

Caan, C. M. (2011). Coping Medied th Relationship between intelligence (EI) andacademic achievement. Internasional journal of psychological, students' emosiona and academic engagement, volume 36, issue 1

Chubba, D. (2007). hubungan antara kecerdasan emosional dengan prestasi belajar siswa kelas XI SMA Wachid Hasyim Surabaya. Skripsi sarjana, fakultas psikologi, UIN Malang.

Cox, J. D. (2011). Emotional intelligence and its role in collaboration. Proceedings of ASBBS, ASBBS Annual Conference: Las Vegas.Volume 18, Number 1.

Ginanjar, A. (2003). ESQ power sebuah inner journey melalui Al-Ihsan. Jakarta: Arga.

Goleman, D. (1999). Emosional intelligence, kecerdasan emosional (mengapa EI lebih penting daripada IQ). Jakarta: PT Gramedia Pustaka Utama.

Hamalik, O. (2010). Psikologi belajar dan mengajar. Cet. VII; Bandung: Sinar Baru Algensindo.

Hasan, M. I. (2001). Pokok-pokok statistik 2 (statistik inferensif). Cet 6; Jakarta: PT Bumi Aksara.

Hidayah, N. (2010). Peningkatan prestasi belajar matematika melalui pendekatan CTL (contextual teaching and learning ) pada siswa kelas IV SDN Madyopuro I di Malang. Skripsi Universitas Islam Negeri Maulana Malik Ibrahim Malang.

Sudjana, N. (1996). Statistika pendidikan. Cet. I; Bandung: Remaja Rosdakarya.

Sugiono. (2012). Statistika untuk penelitian. ED. XX. Bandung: Alfabeta. 
Irmawati ${ }^{1)}$, Thamrin Tayeb $^{2)}$, Ridwan Idris ${ }^{3)}$

Syah, M. (2010). Psikologi belajar, Jakarta: Raja Grassindo Persada.

Winarti, E. W. (2011). Penelitian pendidikan. Bengkulu: UNIB Press.

Yadav. N. (2011). Emotional intelligence and its effects on job performance: acomparative study on life insurance sales professionals. International journalof multidisciplinary research, vol.1 issue 8.

Yaumi, M., \& Nurdin, I. (2013). Pembelajaran berbasis kecerdasan jamak (multiple intelligence), Jakarta: Kencana. 